\title{
O conceito de tradução na obra de lúri Lotman: entre intraduzibilidade e liberdade
}

\author{
The concept of translation in Yuri \\ Lotman's oeuvre: between \\ untranslatability and freedom
}

\section{Ekaterina Vólkova Américo*}

Resumo: O presente artigo objetiva abordar o conceito de tradução na obra de lúri Lotman tanto no sentido da tradução como parte do processo de compreensão, por parte do receptor, da mensagem emitida por um emissor, quanto no que diz respeito às traduções de uma língua para outra. Nesse último sentido, a tradução das obras poéticas destaca-se como a mais difícil de ser realizada devido ao adensamento semântico da palavra poética. Os conceitos de Lotman acerca da tradução revelam-se estreitamente relacionados aos trabalhos teóricos de Aleksandr Potebniá e Roman Jakobson. Por fim, abordaremos a tradução da poesia russa no Brasil, em que se destaca o trabalho em parceria entre Boris Schnaiderman e os irmãos Haroldo e Augusto de Campos e com Nelson Ascher. Entre os exemplos mais interessantes desse trabalho em parceria, destacamos a tradução do poema "Dyr, bul, chtchyl", do poeta futurista Alexei Krutchônykh.

Palavras-chave: lúri Lotman; Roman Jakobson; Aleksandr Potebniá; tradução; semiótica.

\footnotetext{
* Professora de Literatura e Língua Russa da Universidade Federal Fluminense. Doutora em Literatura e Cultura Russa pela DLO/FFLCH/USP. E-mail: katia-v@ya.ru
} 
VolKova AMÉRICO, E. - O conceito de tradução na obra de lúri Lotman: entre intraduzibilidade e liberdade

Abstract: This article aims to analyze the concept of translation in Yuri Lotman's oeuvre both in the sense of translation as an element of the understanding process on the part of the receiver of the message issued by issuer, as with regard to translations from one language to another. In this latter sense, the translation of poetic works stands out as the most difficult work due to the semantic density of the poetic word. Lotman's concepts of translation reveal as closely linked to the theoretical work of Aleksandr Potebnia and Roman Jakobson. Finally, we discuss the translation of Russian poetry in Brazil, which highlights the partnership work between Boris Schnaiderman and Haroldo and Augusto de Campos, as well as Nelson Ascher. Among the most interesting examples of this partnership work, we highlight the translation of the poem "Dyr, bul, chtchyl" by futurist Alexei Kruchonykh.

Keywords: Yuri Lotman; Aleksandr Potebnia; Roman Jakobson; semiotics; translation.

\section{Introdução}

No presente trabalho, objetivamos analisar o conceito de tradução na obra de lúri Lotman, semioticista, filósofo, estudioso da cultura e literatura russa. À parte o seu artigo "Problemas da tradução poética”, ele não deixou estudos de caráter especificamente teórico que elucidassem a sua concepção das questões de tradução. Portanto, com o intuito de isolar esse conceito na sua obra, optamos por localizar a palavra "tradução" em seus textos para depois analisar em que sentido ele é aplicado. Porém, devido ao grande volume de textos escritos por Lotman (mais de 800 ensaios), limitamo-nos apenas àqueles que foram traduzidos por VóLKoVA AMÉRICO (2012), entre eles: “O problema do texto”, “O problema da tradução poética”, “A cultura como inteligência coletiva e os problemas da inteligência artificial”, "O fenômeno da arte", "O fenômeno da cultura”, "A semiótica da cultura e o conceito de texto", "Sobre a dinâmica da cultura".

Não seguimos a ordem cronológica em que o termo aparece nos textos lotmanianos, na verdade a invertemos. Começamos pela análise do seu uso em "A cultura como inteligência coletiva e os problemas da inteligência artificial", 
VóLKOVA AMÉRICO, E. - O conceito de tradução na obra de lúri Lotman: entre intraduzibilidade e liberdade

de 1977, e terminamos com "O problema da tradução poética”, de 1964. De qualquer forma, do ponto de vista cronológico, o termo sofre uma considerável ampliação: se nos primeiros textos ele é usado para definir tradução literária, nos trabalhos posteriores o seu significado estende-se para tradução entre diferentes linguagens culturais.

Antes de abordar casos concretos do uso do conceito "tradução" na obra lotmaniana, julgamos necessário recorrer a um dos trabalhos fundamentais para a teoria da tradução: o artigo "Aspectos linguísticos da tradução" (1974 [1959]), de Roman Jakobson. Além de ser precursor direto da Escola Semiótica de TártuMoscou, liderada por Lotman, Jakobson mantinha estreito contato com os semioticistas, linguistas e críticos literários soviéticos e, inclusive, em 1966, durante a sua ida à União Soviética, participou de reuniões da Escola. Tudo isso permite afirmar que Lotman conhecia bem os seus trabalhos e apoiava-se neles. No artigo citado, Jakobson alega a existência de diferentes tipos de tradução. Em primeiro lugar, ele define a tradução intralingual, que explica os signos verbais por meio de outros signos da mesma língua; depois, a tradução interlingual, a passagem de uma língua para outra, e, por fim, a tradução intersemiótica, em que os signos verbais são transpostos em signos não verbais.

\section{Da linguagem do meu "eu" para a linguagem do teu "tu"}

Adotando essas definições como um ponto de partida, vejamos em que contexto aparece o conceito de tradução na obra de Lotman. Acreditamos que o trecho a seguir é fundamental:

Dessa forma, o ato de comunicação (de todo modo bastante complexo e, portanto, valioso do ponto de vista cultural) deve ser analisado não 
VolKova AMÉRICO, E. - O conceito de tradução na obra de lúri Lotman: entre intraduzibilidade e liberdade

como um simples deslocamento de uma mensagem, a qual permanece adequada a si mesma, da consciência do emissor à consciência do receptor, e sim como uma tradução de um texto da linguagem do meu "eu" para a linguagem do teu "tu". A própria possibilidade dessa tradução é determinada pelo fato de que os códigos de ambos os participantes do ato comunicativo, embora não sejam iguais, formam pluralidades intermitentes (LOTMAN 2001: 563). ${ }^{1}$

Nesse trecho, retirado do artigo "A cultura como inteligência coletiva e os problemas da inteligência artificial” (2001 [1977]), a tradução aparece como uma parte essencial do processo de comunicação mesmo entre os falantes da mesma língua. Essa definição de tradução não coincide com nenhuma das formulações sugeridas por Jakobson. Aqui não se trata de uma "tradução intralingual", pois Lotman não se refere à explicação de um signo verbal por meio do outro e sim à transmissão da mesma mensagem verbal de um indivíduo a outro.

No entanto, ambos os teóricos certamente se baseiam nas ideias de um dos mais importantes precursores dos estudos literários e linguísticos russos, Aleksandr Potebniá (1835-1891) que, por sua vez, fundamentava-se no conceito innere Sprachform, de Wilhelm von Humboldt. Eis como Potebniá entende a palavra:

Distinguimos em uma palavra a sua forma exterior, ou seja, um som inteligível, o conteúdo objetivado por meio do som e a forma interior, ou um significado etimológico mais próximo, por meio do qual o conteúdo é expresso (POTEBNIÁ 2010 [1862]: 156).

Torna-se evidente que, ao definir a tradução intralingual, Jakobson se apoiou na noção de "forma interior" de Potebniá, que afirmava que o significado de uma palavra é entendido a partir das outras palavras

1 Todas as traduções das obras, que aparecem com títulos transliterados do russo na bibliografia, são da autora. 
VóLKOVA AMÉRICO, E. - O conceito de tradução na obra de lúri Lotman: entre intraduzibilidade e liberdade

etimologicamente mais próximas. Assim, mesmo não conhecendo a palavra, podemos entendê-la se conseguirmos distinguir nela uma raiz já conhecida.

Já a posição de Lotman é diferente. Ele refuta a própria possibilidade de transmitir exatamente o mesmo conteúdo, principalmente quando não se trata de uma palavra isolada e sim de um conjunto, de um texto. Por exemplo, ele questiona o seguinte esquema do ato comunicativo, sugerido por Roman JAKOBSON (1960):

CONTEXTO

MENSAGEM

EMISSOR RECEPTOR

CONTATO

CÓDIGO

Segundo LotMAn (2001), a mensagem criada pelo emissor nem sempre é a mesma que chega até o receptor, pois essa cadeia comunicativa estará sujeita a distorções (ruídos) e, como resultado, o texto transmitido do emissor para o receptor pode sofrer alterações consideráveis e até transformar-se em uma nova mensagem, um novo texto. A palavra-chave nesse processo é "indivíduo". É justamente a individualidade dos seres humanos que gera "defeitos" na transmissão de uma mensagem e é por isso que Lotman denomina esse processo de "tradução". É assim que surgem novas mensagens, novos textos de cultura. Além do papel da individualidade humana nesse processo, Lotman ainda destaca a imprevisibilidade do seu resultado.

Porém, isso resultaria necessariamente na impossibilidade de transmitir a mensagem? Significaria que o receptor não entenderia o emissor? Encontramos a resposta nas seguintes linhas:

Essa situação não teria saída se na parte percebida da mensagem não houvesse um indício do modo como o receptor deve transformar a sua 
VolKova AMÉRICO, E. - O conceito de tradução na obra de lúri Lotman: entre intraduzibilidade e liberdade

personalidade para compreender a parte perdida da mensagem (LOTMAN 2001: 563).

Certamente, na linguagem semiótica esse "indício" corresponderia à noção de "código", uma das fundamentais para a semiótica lotmaniana. Para que os dois indivíduos se entendam, para que o receptor consiga "decodificar" a mensagem do emissor, é necessário que ambos dominem o mesmo sistema de códigos linguísticos e culturais.

Por outro lado, quando o processo de "decodificação" é prejudicado por divergências individuais significativas entre os interlocutores, surge o fenômeno que Lotman chama de "intraduzibilidade", o que, porém, não é entendido por ele como algo negativo:

Dessa forma, o mecanismo interno da cultura pressupõe uma especificação tanto das linguagens isoladas, quanto dos nós fechados surgidos (as "personalidades"), o que cria uma situação de intraduzibilidade dos textos que surgem nessas linguagens ou dos modelos do mundo que organizam esses mundos pessoais. Como entre os elementos, tanto dos textos quando dos modelos, não há e nem pode haver correspondências com o mesmo significado, a tradução exata é, nesse caso, impossível por princípio. Surgem as situações semelhantes às da tradução artística: a necessidade da tradução, impossível de antemão, obriga a estabelecer correspondências ocasionais ou aquelas que possuem um caráter metafórico. $\mathrm{Na}$ tradução, o elemento do texto que está sendo traduzido pode corresponder em certa medida a um conjunto de elementos, e viceversa. O estabelecimento de uma correspondência sempre subentende uma escolha, está ligado a dificuldades e possui um caráter de descoberta, insight. É justamente essa tradução do intraduzível que representa o mecanismo de criação da nova ideia. Em sua base não está uma transformação unívoca, mas um modelo aproximado, uma assimilação, uma metáfora (LOTMAN 2001: 565-566).

A "intraduzibilidade" é responsável não só pelo surgimento de novos textos, mas também de novas linguagens culturais. A comunicação entre essas últimas torna-se possível por meio da "tradução intersemiótica", destacada por 
VóLKOVA AMÉRICO, E. - O conceito de tradução na obra de lúri Lotman: entre intraduzibilidade e liberdade

Jakobson. Por exemplo, a literatura e o cinema são duas linguagens da cultura. Como uma mensagem pode ser transmitida de uma para outra?

Lembremos do romance Doutor J ivago (1955), de Borís Pasternak. Ele foi escrito no contexto de perseguições políticas cada vez mais severas na União Soviética, em que o caráter imprevisível da individualidade do poeta desafiava o poder. Uma década depois, o romance foi adaptado para o cinema (traduzido para a linguagem cinematográfica) no Ocidente pelo diretor britânico David Lean, que, por razões políticas, não pôde filmar na Rússia, e por isso criou a sua própria visão, um tanto estereotipada, da história russa. Além disso, o filme não reproduziu o substrato poético da obra original. Contudo, ele foi tão bem recebido, que se tornou, no Ocidente, muito mais conhecido do que o próprio romance. Nesse caso, o processo de tradução intersemiótica e intercultural gerou um novo texto que, sem dúvida, enriquece a cultura universal.

Ainda no que diz respeito ao trecho citado, a menção da tradução artística como um dos exemplos mais evidentes de intraduzibilidade não é ocasional, pois justamente os textos desse tipo são extremamente individualizados e semantizados. Já que encontramos dificuldades mesmo na transmissão de mensagens entre os falantes do mesmo idioma, elas seriam naturalmente muito maiores na transmissão de textos artísticos e especialmente quando se trata de uma tradução interlingual que também sempre é intercultural.

\section{3. "A tradução do intraduzível"}

Segundo Lotman, entre todos os textos da cultura, o mais difícil de ser traduzido (nesse caso, trata-se também da tradução de uma língua para outra) é o texto artístico, literário. Isso se deve ao fato de que, nele, mais do que nunca, predomina o fator individual, imprevisível. Novamente encontramos semelhanças com as posições de Aleksandr Potebniá, que afirmava: 
VolKova AMÉRICO, E. - O conceito de tradução na obra de lúri Lotman: entre intraduzibilidade e liberdade

A arte é uma linguagem do artista; assim como é impossível transmitir, por meio da palavra, um pensamento para outra pessoa, pois despertamos nele apenas o seu próprio pensamento, é impossível transmiti-lo em uma obra de arte; por isso o conteúdo dessa última é desenvolvido já por aqueles que a percebem e não pelo artista (POTEBNIÁ 2010: 163).

Em 1964, Lotman lançou o seu primeiro livro Curso de poética estrutural, que fundamentou o surgimento da nova ciência, a semiótica, na União Soviética. Nele, a arte em geral é vista como uma estrutura construída na base da língua. Assim, no capítulo "O problema do texto", a comparação entre o texto linguístico e o literário permite traçar as propriedades essenciais deste último:

O texto é um sinal de um determinado conteúdo, que em sua individualidade está ligado à individualidade desse texto. Neste sentido, há uma profunda diferença entre a compreensão linguística e literária do texto. 0 texto linguístico permite expressões diferentes do mesmo conteúdo. Ele é traduzível e, por princípio, indiferente às formas de gravação (por meio de som, caracteres, sinais telegráficos etc.). 0 texto de uma obra literária, por princípio, é individual. Ele é criado para um conteúdo específico e, considerando a referida relação entre o conteúdo e sua expressão em um texto literário, não pode ser substituído por nenhum outro texto adequado em termos de expressão, sem que o plano do conteúdo seja alterado (LOTMAN 1994: 206).

O ensaio "O problema da tradução poética", também parte do Curso de poética estrutural, aborda as dificuldades que os tradutores podem encontrar ao verterem os textos literários de um idioma para outro, partindo do princípio que o mais difícil de ser traduzido é o texto poético, dotado de complexas ligações semânticas:

Justamente no texto literário (e, especialmente, na poesia), na fusão do plano linguístico geral de conteúdo e do plano de expressão, na 
VóLKOVA AMÉRICO, E. - O conceito de tradução na obra de lúri Lotman: entre intraduzibilidade e liberdade

estrutura complexa do signo artístico, é que surge o "efeito de intraduzibilidade" (LOTMAN 1994: 235).

Essa ideia converge com a de Roman Jakobson, que defendeu a impossibilidade de tradução da poesia:

O trocadilho, ou, para empregar um termo mais erudito e talvez mais preciso, a paronomásia, reina na arte poética; quer esta dominação seja absoluta ou limitada, a poesia, por definição, é intraduzível. Só é possível a transposição criativa: transposição intralingual - de uma forma poética a outra -, transposição interlingual ou, finalmente, transposição inter-semiótica - de um sistema de signos para outro, por exemplo, da arte verbal para a música, a dança, o cinema ou a pintura (JAKOBSON 1974: 72).

Atentaremos para a expressão "transposição criativa", pois ela remete ao esquema lotmaniano do processo de comunicação como resultado do qual são criados novos textos. A "intraduzibilidade", portanto, aparece tanto para Jakobson, quanto para Lotman como um fator instigante para o processo criativo.

A complexidade específica do texto poético provém do adensamento das ligações semânticas em dois níveis: intratextual e extratextual. No primeiro encontramos obstáculos no âmbito fonológico e gramatical, também citados por Jakobson:

As principais dificuldades na tradução de um texto literário estão relacionadas com um outro aspecto: a necessidade de transmitir as relações semânticas que surgem no texto poético nos níveis fonológico e gramatical. Se no nível fonológico se tratasse apenas da reprodução de certas onomatopéias, aliterações ou outros elementos do gênero, as dificuldades seriam muito menores. Porém, aquelas relações semânticas específicas que surgem devido às alterações - no texto poético - da relação entre o envoltório sonoro da palavra e a sua semântica, bem como a semantização do nível gramatical, pelo visto, não podem ser traduzidas com precisão (LOTMAN 1994: 237). 
VolKova AMÉRICO, E. - O conceito de tradução na obra de lúri Lotman: entre intraduzibilidade e liberdade

Outra dificuldade relacionada à tradução semanticamente correta da poesia consiste na transposição do seu sistema métrico e rítmico. Esse assunto foi abordado em vários trabalhos de Mikhail Gaspárov, que, além de ter participado da Escola Semiótica de Tártu-Moscou, também era tradutor de poesia. As complexas associações semânticas que estão por trás do metro e do ritmo na poesia foram abordadas em seu livro 0 metro e o sentido, em que ele afirmou:

[...] a escolha de uma palavra ou um metro por si só já significa dar uma pista para o leitor sobre a cadeia de associações semânticas que o seguem. Algumas delas são mais fortes, outras mais fracas, porém todas são significativas tanto para o escritor, quanto para o leitor. Ao se limitar à análise da "integridade" de uma obra, corremos risco de perder essas associações e dessa forma empobrecer o seu conteúdo.

Graças a M. M. Bakhtin o conceito de "palavra alheia" virou moda; nenhum escritor escolhe as suas palavras pela própria vontade, ele as recebe das mãos dos seus precursores [...]. O mesmo acontece com um o metro poético que, salvo raríssimas exceções, só pode ser "alheio" e herdado dos antecessores (GASPÁROV 1999: 14).

Assim, ao escolher um dado pé em sua obra poética, o autor se refere a todo o conjunto de obras poéticas em que ele foi usado. Esses "precursores" são evidentes para um leitor perspicaz que pertence à mesma cultura, mas podem não ser tão claros para um tradutor/leitor estrangeiro. Segundo Lotman, nesse caso formam-se novas associações, próprias para cada cultura.

A semantização presente no nível intratextual, na forma como a poesia é organizada fonológica, gramática e metricamente, remete ao nível extratextual, que engloba o contexto em que essa obra foi criada e em que ela é percebida e traduzida. A obra poética em sua totalidade representa um código. Esse código, também presente no texto linguístico, no texto literário é muito mais complexo: 
VóLKOVA AMÉRICO, E. - O conceito de tradução na obra de lúri Lotman: entre intraduzibilidade e liberdade

No entanto, a proporção entre texto e código na literatura é muito mais complexa do que no idioma. Nem sempre o código é dado para o ouvinte com antecedência. Mais frequentemente, o ouvinte deve retirá-lo e construí-lo à medida de sua percepção artística do texto, elaborado para revelar aos poucos para o receptor os princípios da construção. 0 artista traz para o público um programa de construção da estrutura, cuja compreensão transforma os detalhes do texto em elementos estruturais. Neste sentido, o artista e seu público estão na posição de pessoas que desde o início não falam a mesma língua (LOTMAN 1994: 237).

Assim, surge a ideia de um jogo entre o autor e o leitor, em que o primeiro deixa as pistas (códigos) e o segundo deve descobri-las para avançar. Se o leitor nem sempre é capaz de decifrar uma mensagem criada na mesma língua, o problema torna-se ainda maior se falarmos de um texto poético e da sua tradução para outra língua, pois, nesse processo,

(...) surge a percepção inadequada, que se manifesta com maior intensidade quando o autor e o leitor são separados por um longo período de tempo ou, na tradução, pela diferença entre as culturas nacionais (LOTMAN 1994: 239).

A comparação entre o modelo do ato de comunicação que apresentamos no início e as propriedades do texto poético revela um fato paradoxal: se no texto linguístico é o código que permite a transmissão do núcleo semântico do emissor para o receptor com a menor perda possível, no segundo caso ocorre o contrário: é justamente o código que dificulta a percepção e, por conseguinte, a tradução. Além disso, não se trata de um código só: se uma obra poética em sua totalidade representa um código, cada um dos seus elementos também é um código: a estrutura, o metro, o ritmo, a gramática, até a palavra e o som.

0 interesse especial de Lotman pela linguagem poética e as possibilidades de sua tradução tem uma longa "pré-história". 0 adensamento semântico foi observado em relação à palavra poética por Potebniá, que a comparava, inclusive, com uma obra de arte (PotEBnIÁ 2010: 165). Essa ideia 
VolKova AMÉRICO, E. - O conceito de tradução na obra de lúri Lotman: entre intraduzibilidade e liberdade

influenciou significativamente as gerações posteriores de poetas e teóricos na Rússia. No limiar dos séculos XIX-XX, em muito incentivados por trabalhos de Potebniá, os poetas simbolistas, que viam a palavra como um símbolo, conseguiram fazer a poesia renascer após um longo domínio da prosa, preparando o terreno para o assim chamado Século de Prata, um verdadeiro renascimento da poesia na literatura russa nas primeiras duas décadas do século $X X$. Esse auge inspirou os estudos da palavra poética por formalistas, bem como as experiências da vanguarda futurista.

$\mathrm{Na}$ poesia dos futuristas russos, a palavra recebeu uma dimensão jamais vista antes. Se Maiakóvski é conhecido por seus neologismos, cuja tradução é um verdadeiro desafio, seus colegas Velimir Khliébnikov e Aleksei Krutchônykh se empenharam em criar uma nova linguagem, a qual denominaram transmental (záum). Um dos objetivos era criar uma espécie de protolíngua, na tentativa de provar que o sentido pode ser transmitido por meio das letras e até do som. Em teoria, tal linguagem dispensaria tradução por ser transmental e, portanto, também transcultural. Vejamos, no capítulo a seguir, como esses aspectos de cunho teórico e poético se refletiram em alguns projetos de tradução da poesia russa, em coautoria, realizados no Brasil por Boris Schnaiderman e outros tradutores.

\section{Da teoria à prática}

Ao recorrermos às traduções brasileiras da poesia russa, o primeiro que chama a atenção é a raríssima presença do maior poeta russo Aleksandr Púchkin, visto que parte notável da sua prosa já possui versões em português. Certamente, a explicação dessa ausência encontra-se justamente na forma poética, em seu adensamento semântico, apontado por Potebniá, Jakobson e Lotman, multiplicado pelas dificuldades relacionadas às distâncias temporais e 
VóLKOVA AMÉRICO, E. - O conceito de tradução na obra de lúri Lotman: entre intraduzibilidade e liberdade

culturais, pois se trata de um poeta que criava na primeira metade do século XIX. Outro fato interessante é que as primeiras e mais conhecidas traduções diretas da poesia puchkiniana foram feitas a quatro mãos, por Boris Schnaiderman e Nelson Ascher (PúcHKIN 2006 [1999]). Em relação a essa coautoria, no prefácio da edição brasileira, Schnaiderman destaca que a Nelson Ascher "cabe todo o mérito da elaboração poética em português", sugerindo, portanto, que a sua participação consistiu na tradução literal dos textos e esclarecimentos acerca de suas particularidades semânticas, fonéticas e rítmicas. Ao que parece, as traduções em parceria, feitas por um grupo de tradutores, mostram-se como uma opção extremamente frutífera e criativa de superar as dificuldades relacionadas à tradução poética.

Porém, o projeto de tradução em parceria mais famoso é, sem dúvida a coletânea Poesia russa moderna (2012), preparada por Schnaiderman e os irmãos Augusto e Haroldo de Campos, que já se tornou uma obra clássica no Brasil. No prefácio, Schnaiderman faz observações extremamente preciosas sobre essa experiência de tradução poética:

Temos a impressão de que o português se presta melhor que outras línguas para a reprodução da "trilha sonora" dos poemas russos. Procuramos, pois, utilizar estes recursos da língua em nosso trabalho. A fidelidade que buscamos foi a fidelidade integral, isto é, semântica, fonológica e gráfica. De nada nos adiantaria reproduzir apenas o "conteúdo", a "mensagem" de um poema, pois, a nosso ver, limitar a tradução de poesia a este aspecto seria um empobrecimento e uma deformação. Na recriação do texto, usamos um grau considerável de liberdade (...) que não é de modo algum incompatível com a verdadeira fidelidade ao original (SCHNAIDERMAN 2012: 37).

A noção de liberdade expressa aqui nos faz lembrar as afirmações de Jakobson e Lotman de que a única possibilidade de traduzir um texto poético é a criatividade, o que, em alguns casos, pode resultar até na geração de um novo texto. É justamente por isso que no trecho citado surge a palavra "recriação". 
VolKova AMÉRICO, E. - O conceito de tradução na obra de lúri Lotman: entre intraduzibilidade e liberdade

No "Prefácio da $2^{\mathrm{a}}$ edição" da coletânea, os autores chamam atenção para a forte presença dos futuristas, entre eles os criadores da linguagem transmental, Velimir Khliébnikov e Alexei Krutchônykh. Certamente, a tradução da poesia transmental foi o maior desafio do grupo, principalmente por se tratar da obra de Krutchônykh, representado na coletânea inclusive por seu famigerado poema "Dyr, Bul, Chtchyl" de 1913, composto por palavras e sons aparentemente sem nenhum significado:

\author{
Dyr, bul, chtchyl \\ ubachtchur \\ skum \\ ví so bu \\ rlez
}

No texto russo encontramos:

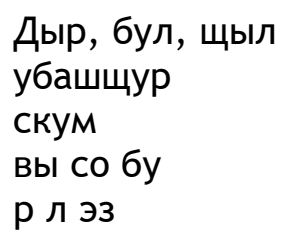

Ao se comparar a versão com o texto "original", descobrimos que a tradução nesse caso consiste em apenas transliterar a grafia das palavras do alfabeto cirílico para o latim. Acreditamos que essa foi a melhor escolha a ser feita, pois se trata de palavras e sons inexistentes em russo. Embora nesse caso só Augusto de Campos conste como tradutor, essa decisão provavelmente foi apoiada por todos.

O poema de Krutchônykh é um fenômeno à parte, algo comparável ao Quadrado negro de Kazimír Maliévitch, que, ao mesmo tempo, recusa e resume em si toda a história anterior da arte. Assim como em Maliévitch, toda plenitude semântica da palavra poética aqui é reduzida à sua forma, nesse caso às letras e aos sons. Trata-se da decomposição de palavras (SCHNAIDERMAN 2012: 24) na 
VóLKOVA AMÉRICO, E. - O conceito de tradução na obra de lúri Lotman: entre intraduzibilidade e liberdade

tentativa de criar uma obra que dispensaria tradução, que possa ser compreendida por todos.

Apesar de o poema ser tão pequeno e aparentemente non-sense, foram-lhe dedicados vários estudos científicos, inclusive um artigo de um dos maiores especialistas em poesia do Século de Prata, Nikolai Bogomólov (2005). Inserindo o poema no contexto da época da sua criação, o autor enumera algumas possibilidades de leitura:

1. É um procedimento de epatage, ou estranhamento, se usarmos o termo do formalista Víktor Chklóvski, para chamar atenção ao fenômeno da arte, à sua forma, e, principalmente, à palavra. Não é por acaso que os poetas futuristas proclamavam a ideia da "palavra como tal", por exemplo, no primeiro manifesto do futurismo russo Bofetada no gosto público, de 1912.

2. Krutchónykh imita os sons característicos da fonética da língua russa, criando um efeito interessante: é como se um estrangeiro escutasse as palavras russas sem entender o seu sentido.

3. Há também tentativas de imitar a poesia japonesa, por exemplo, os poemas curtos tanka, compostas por cinco linhas, assim como de reproduzir os sons de línguas africanas e túrcicas, remetendo ao componente "tártaro", bárbaro da cultura e língua russa.

4. É uma tentativa de abreviar, compactar a língua, usando apenas as sílabas e os fonemas no lugar das palavras inteiras.

5. É uma imitação do barulho da cidade, tão glorificada na poesia dos futuristas.

6. As sílabas do poema remetem a algumas poesias mais correntes da época, como, por exemplo, as de Vladímir Nárbut e Nikolai Gumiliov.

Essas possiveis leituras do poema de Krutchiónykh, analisadas do ponto de vista lotmaniano, representam um código hiperbolizado, uma combinação de elementos intratextuais e extratextuais, confirmando a ideia de que uma 
VolKova AMÉRICO, E. - O conceito de tradução na obra de lúri Lotman: entre intraduzibilidade e liberdade

obra não pode ser compreendida sem levar em conta o contexto da sua criação. É curioso observar como uma obra cujo objetivo era destruir toda a cultura e arte anteriores, na verdade se apoia totalmente nelas.

Trata-se de um caso à parte, um texto intraduzível por princípio, ou melhor, um texto que dispensa tradução. Esse poema é uma espécie de "desnudamento de procedimento" (recorrendo de novo a um termo de Chklóvski), que objetiva revelar a essência da poesia e da palavra poética. Podemos dizer, portanto, que a sua tradução, feita por meio de uma simples transliteração, é, ao mesmo tempo, um desnudamento da arte da tradução.

É interessante notarmos ainda que a decodificação do poema por parte do leitor requer todos os três tipos de tradução propostos por Jakobson. É uma tradução intralingual porque buscamos o sentido das "palavras" do poema comparando-as com a etimologia das palavras russas que realmente existem. Assim, o fonema inicial "dyr" nos remete à palavra "dyrá" que pode ser traduzida como buraco. É também uma tradução interlingual, pois se trata de uma obra concebida para ser entendida em todas as línguas (não é por acaso que ela imita russo, japonês, línguas túrcicas e africanas). Podemos falar de tradução intersemiótica porque se trata de uma nova linguagem, a linguagem transmental. Por fim, é um exemplo de "tradução da linguagem do meu eu para a linguagem do teu tu" lotmaniana, pois cada um dos leitores terá a sua própria percepção da obra. Portanto, a opção dos tradutores de não interferir nos códigos deixados pelo autor abre ao leitor as inúmeras possibilidades de sua leitura e interpretação.

\section{Bibliografia:}

Bogomólov, N. "Dyr, Bul, Schyl” v kontiékste epokhi. ("Dyr, bul, chtchyl” no contexto da época). In: NLO, n. 72, 2005, pp. 172-192. 
VóLKOVA AMÉRICO, E. - O conceito de tradução na obra de lúri Lotman: entre intraduzibilidade e liberdade

GASPÁRov, M. Mietr i smysl. (0 metro e o sentido). Moscou, RGGU, 1999.

JAKOBSON, R. Aspectos linguísticos da tradução. In: Linguística e comunicação. [Trad. de Izidoro Blikstein e José Paulo Paes]. São Paulo: Editora Cultrix, 1974: 63-72.

Closing statement on linguistics and poetics. In: Style in Language. Cambridge MA: MIT Press, 1960, pp. 353-357.

LOTMAN, I. Kultúra kak kollektívnyi intellekt i probliémy iskússtvennogo rázuma. (A cultura como inteligência coletiva e os problemas da inteligência artificial). In: Semiosfera. São Petersburgo: Iskússtvo-SPB, 2001: 557-567.

Probliéma tiéksta. ( 0 problema do texto). In: Liéktsii po strukturálnoi poétike. (Curso de poética estrutural). Moscou: Gnozis, 1994: 201-214.

Probliéma stikhovógo perevoda. (0 problema da tradução poética). In: Liéktsii po strukturálnoi poétike. (Curso de poética estrutural). Moscou: Gnozis, 1994: 235-239.

Potebniá, A. Mysl i iazyk. (Pensamento e linguagem). Moscou: Labirint, 2010.

Púchkin, A. A dama de espadas. Prosa e poemas. [Tradução de Boris Schnaiderman e Nelson Ascher]. São Paulo: Editora 34, 2013.

Poesia russa moderna. [Tradução de Augusto de Campos, Haroldo de Campos, Schnaiderman, Boris]. São Paulo: Perspectiva, 2012.

Schnalderman, B. Prefácio. In: A dama de espadas. Prosa e poemas. [Tradução de Boris Schnaiderman e Nelson Ascher]. São Paulo: Editora 34, 2013: 7-18.

Prefácio à $1^{a}$ edição. In: Poesia russa moderna. [Tradução de Augusto de Campos, Haroldo de Campos, Schnaiderman, Boris]. São Paulo: Perspectiva, 2012: 17-38.

Prefácio à $2^{a}$ edição. In: Poesia russa moderna. [Tradução de Augusto de Campos, Haroldo de Campos, Schnaiderman, Boris]. São Paulo: Perspectiva, 2012: 39-50.

VólKova AmÉRICO, E. Alguns aspectos da semiótica da cultura de lúri Lotman. Tese de doutorado. USP, 2012. 